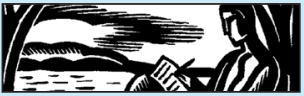

\title{
Till Death Did Him Part: Thomas Hardy and His Funerals
}

\author{
Charles Lock
}

University of Copenhagen

[J.M. Barrie] was especially tickled by Hardy's preoccupation with plans for his own burial-plans, continuously changed. 'One day Hardy took me . . . to see the place where he's to be buried, and the next day he took me to see the place where he would like next best to be buried. Usually he says he is to be buried between his wives; but sometimes, so many inches nearer the first; sometimes, so many inches nearer to the second.'

Cynthia Asquith, Portrait of Barrie (London: James Barrie, 1954), p. 107

The wrongness of two funerals and the wretchedness of Florence's later years bring a sombre end to any account of Hardy.

Claire Tomalin, Thomas Hardy: The Time-Torn Man

(London: Penguin, 2006), p. 377

\section{ABSTRACT}

This essay considers Hardy's two funerals-for his ashes at Poets' Corner, for his heart at Stinsford-in the light of their consequences for life-writing: the absence of a single resting-place, and the narrative demands of synchronicity in telling of two funerals. This division of the body was the consequence of an extraordinary lack of precision in Hardy's own will, the composition, wording and interpretation of which are examined here in some detail. Attention is also paid to the single grave at Stinsford that holds the remains of Hardy and both his wives in diverse modalities of the invisible.

Keywords: Thomas Hardy, wills and testaments, ashes, funerals, heart-burials 
Mark Ford's Thomas Hardy: Half a Londoner (2016) takes Hardy's own identifying term as its argument, thereby endorsing Hardy's protest against the misleading way in which he had been both critically and socially confined to 'Wessex'. Hardy's beginning is single and unambiguous: he was born in the cottage at Higher Bockhampton, Dorset, now known as 'Hardy's Birthplace'. Yet his ends are complex: his corpse was divided and for each part both a funeral and a burial was held. Taking Hardy's ends for his own beginning, Ford in his opening chapter, 'In Death Divided', narrates how those body-parts came to symbolise the topographical divisions of Hardy's biography, now perpetuated in two graves: one (the corpse-without heart-cremated) in Westminster Abbey, the other (the heart) in Stinsford Churchyard.

'In Death Divided' echoes against the Biblical phrase, 'In death they were not divided'. 'Whereas two lovers may, regrettably, be sundered in death, a single grave holding a loving couple invites epitaphic celebration of a well-matched pair, eternally united. 'In death they were not divided' affirms a union beyond or despite that parting by death that the marriage service anticipates, and that the law acknowledges as terminal. Rather different from either of these is the fate of Thomas Hardy, of whom it might be said: till death did him part. Subjected to post-mortem surgery, one corpse would furnish the matter for two funeral services, held simultaneously a hundred miles apart, his remains now resting in two burial plots no less sundered. Where, then, might Thomas Hardy's life be said properly to have ended? And at which of the burial-sites, if at either, might the devoted reader sense the author's aura or 'presence'? Where does one feel that due homage has been paid?

Hardy had imagined in verse many instances of trouble in mortality, whether in 'The Levelled Churchyard' where 'each to each exclaims in fear/"I know not which I am!"' or 'In Death Divided', where the poet imagines a time when he and his beloved will be buried far from each other, neither monument acknowledging the other:

The simply-cut memorial at my head

Perhaps may take

A rustic form, and that above your bed

A stately make;

No linking symbol show thereon for our tale's sake.

And in the monotonous moils of strained, hard-run

Humanity,

The eternal tie which binds us twain in one

No eye will see

Stretching across the miles that sever you from me. ${ }^{2}$ 
An illicit, covert love, implicitly between persons of divergent classeshe rustic, she stately ${ }^{3}$ - will have no memorial; this tends to be the postmortem state of affairs, or most of them. Hardy himself, much more unusually, even among the twice-wed, is buried with both his wives. Yet, not all of him being in that grave, we might hear him phrase the thread that links Stinsford and Westminster as 'stretching across the miles that sever me from me'.

Thomas Hardy's last will, dated 24 August 1922, was drawn up in full awareness of what was at stake and what problems had to be forestalled. Of paramount concern was not property, whether messuages or chattels, but the disposal of a body, which is in law neither land nor possession: the body of the deceased, or of the not-yet-deceased; the body of the one who by his signature attests to the will to be put into effect after his decease:

THIS IS THE LAST WILL AND TESTAMENT of me, THOMAS HARDY, of Max Gate, Dorchester, in the County of Dorset, Esquire, O.M.

And this is the very first item:

1. It is my wish that I may be buried in Stinsford Churchyard Dorset near to the Grave of my parents and if possible in my wife Emma's Grave or close at the foot thereof according to consideration detailed in my directions to my Executors on a separate paper. ${ }^{4}$

The phrase following 'thereof' created trouble, as we shall see. In his widow's will, drawn up and signed on 18 May 1937, within five months of her death on 17 October, 'Florence Emily Hardy of "Max Gate", Dorchester, in the County of Dorset, widow of the late Thomas Hardy, O.M., deceased' is concerned first with specifying the responsibilities of the trustees before willing the disposal of her body, as item 3:

3. I wish to be cremated and that my ashes be placed in the grave at Stinsford Churchyard in which my husband's heart is buried and I desire that the inscription which my husband composed with my name and the necessary particulars be placed on the south side of the tomb. ${ }^{5}$

Despite the addition of four codicils in as many months, this Will led to no controversy: Florence was buried as she (and her husband) had willed, and indeed the heart of Thomas Hardy lies in Stinsford Churchyard now, between his two wives: Emma who had died in 1912 and Florence whom he had married in 1914. And yet symmetry is lacking, not to those innocently admiring this rural scene, but to those who know what was willed of the remains: in one grave lies Emma's body, in the other, Florence's 
ashes. This imbalance in matter is but one of the consequences-and that seldom regarded-of a will shockingly and (we suppose) deliberately misconstrued.

It is the responsibility of the one who draws up a will, or any document intended to carry legal force, that linguistic ambiguities be reduced to a minimum and that the wording should uphold and assert the authority of the performative. The formulaic conventions of a will retain in writing, unconcealed, the markers of oral testimony: 'Signed by Thomas Hardy as his will in our presence and by us in his presence.' The problem in Hardy's will lies in the word 'according', which here governs a clause that takes us to a place not 'herein' nor 'heretofore' nor to 'the above' nor to 'the said'. These are all forms of 'intradiscursive deixis', pointing the reader to words, phrases and clauses contained within the present document; in coming upon the phrase 'as above' the reader will keep her eyes on the text, not raise them to the skies. A will, in providing commentary, clarification and interpretation of terms already introduced, should point only to its own specifics. A codicil differs from a will in that its sense depends on reference to specific points of an already existing document: the will. A will needs to be semantically autonomous, self-contained; a codicil, being supplementary, never is. Of course, the phrase 'according to' need not always in legal usage be 'intradiscursive'; it is frequently found in one legal text to refer to another, and within that to a numbered paragraph or article or section. What is fundamental to its legal status, whether for interpretation or for due process, is that the text elsewhere, referred to and identified by such a phrase as 'according to' or 'pursuant upon', must be available in the public sphere. A will must be made public in probate, that is, before it can be executed. One cannot (in an open society) have a legal document stipulating that any of its clauses should be 'in accordance' with a text elsewhere that is unpublished and unavailable-one, let us suppose, to which only the judge has access. Despotism thrives on such.

The value of Hardy's Will is depreciated in and by its very wording: 'according to consideration detailed in my directions to my Executors on a separate paper.' A writer, a lawyer, a teacher: each of us knows that this sentence ought to have stopped 'at the foot thereof'. The implication of the added clause-'or close at the foot thereof according to consideration detailed in my directions to my Executors on a separate paper'-may well be that such a consideration should be limited to the question of where, in relation to Emma's grave, Hardy's body should lie: somewhere within Stinsford Churchyard. But implication carries little weight in the law. The extraordinary aspect of this will is that, 'according to a consideration' that forms no part of the Will, and whose very existence is not affirmed 
(nor its location indicated), the first paragraph of the Will is vulnerable to being modified, countermanded or ignored, and is liable to be rendered invalid by whatever might yet be willed 'on a separate paper'. The authority that a will carries through the sheer presence of its rhetoric has been, by this alternative 'according', utterly compromised. It is unusual that the disposal of the body should be so important as to be given precedence in a will over all other considerations. It is astonishing that, given such prominence, the instructions regarding burial should be so worded as to render its legal weight almost nugatory.

According to $\$ 19$ of Thomas Hardy's Will, Lloyds Bank was named as sole TRUSTEES and EXECUTORS of the Will, while Sydney Cockerell and Florence Emily Hardy were to be appointed as his 'Literary EXECUTORS'. Declining a university education, Cockerell (1867-1962) had elected instead to become a disciple of John Ruskin, subsequently finding employment as secretary to William Morris. In 1908, Cockerell was appointed Director of the Fitzwilliam Museum and there he remained until 1937. Though he and Hardy were friends, they were of very different temperaments. When in 1924 the Balliol Players gave a private performance of the Oresteia at Max Gate, Cockerell and Hardy formed almost the entire audience, and the contrast was recalled by the production's actor-manager, Walter Oakeshott: 'Hardy, small, bright-eyed, quiet, and utterly unassuming; S.C. equally small, but possessive and masterful. ${ }^{6}$ Hardy chose Cockerell from among those he knew of a younger generation, as one extremely well-connected and influential, with the power and competence to get things done. Throughout, Cockerell assumed in effect the role of Executor, for Lloyds Bank played no part in the events immediately following Hardy's death.

Approaching the end, Hardy had remained in bed for four weeks and had barely stirred since 11 December 1927; on 9 January 1928 he seemed to be fading further and Florence summoned Sidney Cockerell by telegram. He arrived at Max Gate that evening, though he was not invited into Hardy's bedroom. Florence had also summoned J. M. Barrie who, a trusted friend of Hardy's since 1907, had grown close to her. ${ }^{7}$ Neither man was admitted to Hardy's presence, as Florence had already intimated in a message to Cockerell: 'If you think it well to be in Dorchester come-only T. must not see you, or even know you are there. ${ }^{8}$ Barrie spent the night in a Dorchester hotel while (somewhat surprisingly) Cockerell slept in his clothes in the dining-room of Max Gate. These two distinguished men, summoned urgently from London yet finding themselves superfluous, would presumably have passed that evening together, either at Max Gate or at Barrie's hotel in Dorchester. ${ }^{9}$ And on their own, to continue the conjecture, they conspired to set in 
motion events far from accordant with Hardy's Will-even though the Will had not yet been opened.

Strangely, given that Hardy's death was evidently near, Barrie chose not to stay to the end but instead returned to London the very next day, on Tuesday 10 January. ${ }^{10}$ There he solicited the support of the Prime Minister and the Editor of the Times in petitioning the Dean of Westminster Abbey, William Foxley Norris, to hold the funeral in the Abbey, and to have Hardy's remains interred in Poets' Corner. (Hardy was not yet deceased.)

Cockerell was kept away from Hardy's bedroom the next day alsoWednesday 11 January-though he remained at Max Gate. Hardy died that evening at 9.05 p.m. ${ }^{11}$ As soon as Hardy's doctor, Dr. E. W. Mann, had signed the death certificate Cockerell made a telephone call to London and Hardy's death was announced that same evening by the BBC at the end of the nine o'clock news. ${ }^{12}$

That evening, before sleeping again at Max Gate, Cockerell opened the Will, without authorization from the Executors (Lloyds Bank) and in the absence of Florence. He laid the Will out on the dining-room table for Florence to see in the morning although he did not display (then, or ever) the 'separate paper' that he claimed, the next morning, to have found in the envelope. The 'instructions' thereon were to cause great shock and distress, immediately to the surviving members of Hardy's family, his brother Henry and his sister Kate, and later, in retrospect, to Florence herself. ${ }^{13}$ The entries in Kate's diary for 12th and 13th January 1928 are moving in their anger and helplessness. Kate and Henry visited Max Gate:

12 [January] We found Eva [Dugdale, Florence's sister], Mr Cockerell, Dr. Mann there with Florence. It seems they want to bury Tom at Westminster Abbey-it seems the wish of Mr Cockerell, Sir James Barrie \& Florence. H. \& I prefer Stinsford of course as we understand he wished to lie there but they say that among his papers is a notice to the effect that 'if the nation desire it otherwise' he can be buried at Westminster A. It is a great grief to us two-but naturally we were ruled right out of it. [... $]^{14}$

That 'notice' among his papers may have been the 'separate paper' detailing 'directions to my executors'. However, neither the 'notice' nor the 'separate paper' has ever been found, 'among his papers' or anywhere else: whether one or two, it or they are presumed to be a fiction concocted by Cockerell. It is generally accepted that Cockerell opened the Will on his own. Did he find the separate paper in the envelope containing the will, and thereon read instructions concerning a site not too far 
from Emma's grave? Or did he find a plan of Stinsford Churchyard that indicated an alternative place for burial? Or did Cockerell find nothing but the Will? If the separate paper was concerned only with Stinsford Churchyard, Cockerell would have thought it wise to destroy it; if, however, on this paper, Hardy had indicated some aspiration (or consent) to be buried in the Abbey, Cockerell would surely have displayed it. Given his considerable authority, he could have invented the instructions, trusting that nobody would have the impudence to challenge him to produce the evidence. 'The apparent non-survival' of that paper, in Millgate's words, "poses serious problems. ${ }^{15}$

Kate's Diary for the following day, Friday 13 January:

13 [Henry] \& I went to [Dorchester] for one or two things \& called at Max Gate on our way back. We saw only Florence who told us incidentally that Tom is to be cremated. This was another staggering blow but we kept 'a stiff upper lip'. [...] Between 8 \& 9 this evening Mr \& Mrs Cowley [the Vicar of Stinsford and his wife] called to say Tom's heart is to be buried at Stinsford. Another staggering blow but still we go on quietly. What a world-wide talk such doings are causing.

It was the Revd. H. G. B. Cowley who devised the compromise whereby the corpse could be divided and the claims of both nation and parish thus be met: Cowley was, after all, about to be denied the opportunity of conducting a most illustrious funeral at Stinsford. The 'heart-burial' placated Kate and Henry somewhat; it meant that one part of the body would not only be buried at Stinsford but would also be spared cremation. ${ }^{16}$ This solution salvaged to some degree the dignity of Stinsford Church and assuaged the hurt felt by Hardy's closest relatives. ${ }^{17}$ Dr. Mann was apparently present during these discussions for he gave his medical assent and called in his senior partner, Dr. Nash-Wortham, who had surgical training, to perform the operation. Between the time of the dividing operation and the day of the two funerals Dr. Mann is said to have been the custodian of Hardy's heart. He kept it in a biscuit-tin. In the midst of misplaced ambitions and vulgar social scrambling, here is a simple domestic detail-though one that led to further gossip (quite unattested) that the cat had got hold of the heart. ${ }^{18}$

Almost everything about this episode is shocking and offensive, but what most appals is that a poet should be ignominiously subjected to so crass a misreading of metaphor. When a poet (or anyone outside a physiological context) speaks of the heart, or to the heart, she is not usually referring to the cardiac organ. In an age more sensitive to rhetoric, the age of Shakespeare, for example, these doings would be unthinkable: imagine 


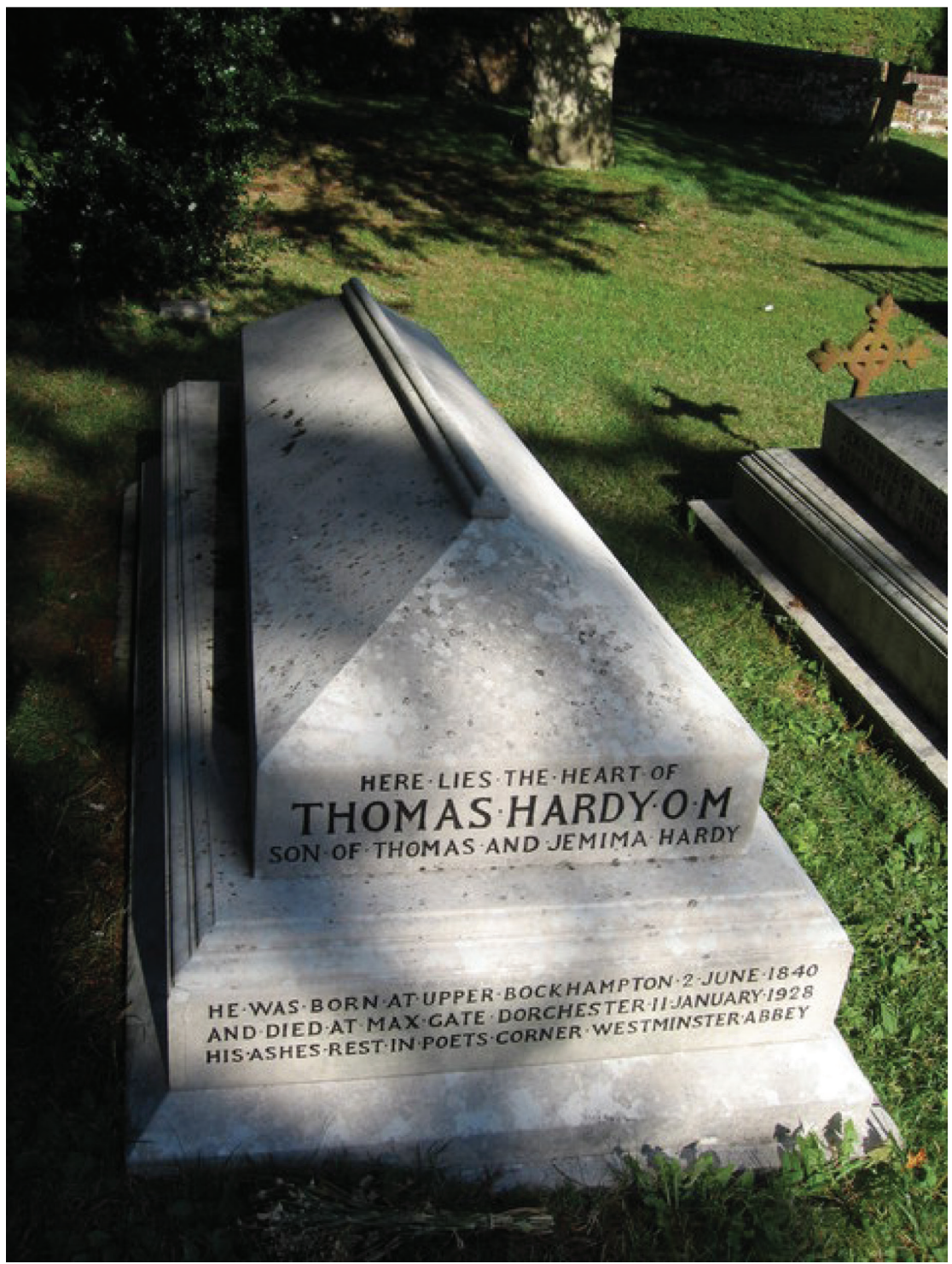

Figure 1. Thomas Hardy's grave, Stinsford churchyard/CC BY-SA 2.0. Caroline Tandy/ Wikimedia commons. 
the royal physician being summoned to investigate surgically whether Queen Mary really did have 'Calais' engraved on her heart. Cockerell's interfering presumptuousness led to much unhappiness. Even the doctors would have needed to keep a stiff upper lip as they went through with the charade, under his orders. Dr. Mann's sensitivity and dry wit endeared him to Hardy's sister Kate. And the elegantly ambiguous inscription on the grave at Stinsford-'Here lies the heart of Thomas Hardy O.M.'-may still touch ours, the more poignantly if we suppress any thought of a cardiac organ kept overnight in a biscuit tin.

Once the surgery had been performed, the heartless corpse was taken in a hearse to Woking Crematorium. ${ }^{19}$ This was the earliest to be constructed in Britain and was first officially used for a cremation in 1885 . Cremation had become legal only in 1884, and Kate's response to the news that her brother was to be cremated-'another staggering blow'-is not a symptom of provincial thinking; cremation remained controversial for decades, though as early as 1910 it was stipulated that for a burial in Westminster Abbey only ashes would be accepted..$^{20}$ Thus one church building — of the highest symbolic importance in the national life-had enforced very early a practice about which the Church of England as an institution would long remain ambivalent. ${ }^{21}$ From the Woking Crematorium, Barrie carried the casket to London by train.

There were to be two funerals held simultaneously, at St. Michael's Stinsford and at the Abbey, on Monday 16 January 1911, at 2 pm. ${ }^{22}$ Cockerell decreed that Hardy's two siblings would be apportioned, one to each, though it was not Cockerell who informed them of this decision, as Kate recorded: 'Dr. Mann came this morning. It seems that I am to go to Westminster Abbey to the funeral tomorrow \& H. to Stinsford. [...] I was frightfully busy all day \& up till midnight. ${ }^{23}$

Dr. Mann accompanied Florence and Kate by train from Dorchester to Waterloo, and then to the Abbey, where they were seated, as chief mourners, with Cockerell. The coffin was carried by as distinguished a set of pallbearers as could be mustered in England: Stanley Baldwin, the Prime Minister, and Ramsay Macdonald, former Prime Minister and Leader of the Opposition, and six writers: Rudyard Kipling, George Bernard Shaw, J. M. Barrie, A. E. Housman, Edmund Gosse and John Galsworthy-each one to this day a name in literary history. With them, the two heads of the colleges at Oxford and Cambridge of which Hardy had been made an Honorary Fellow. ${ }^{24}$ Ten such imposing men to carry one casket? Virginia Woolf was in the congregation and recorded the funeral in her diary for the following day, Tuesday 17 January: '[...] next here is the coffin, an overgrown one; like a stage coffin, covered with a white satin cloth: bearers 
elderly gentlemen rather red \& stiff. ${ }^{25}$ Well described as 'a stage coffin', what seemed to be borne on the shoulders of ten men contained only ashes.

Kate was unimpressed by the occasion: 'It was all very mournful \& hopeless \& strange \& I was relieved when it was over. Then to Sir James Barrie's for another crumb \& a taste of tea, then Waterloo for home. Dr. Mann came right home with me. ${ }^{26}$ She was not alone in finding the funeral hard to endure; T. E. Lawrence (who was not in attendance) wrote to a friend of his distaste at how 'these sleek Deans and Canons were acting a lie behind his name' while the anthropologist and folklorist Edward Clodd-no upholder of traditional values or practices-regarded the dividing of Hardy's body as 'very repellent'. ${ }^{27}$

Florence herself came to regret bitterly that she had acceded to Cockerell's plans, even calling them 'wicked', and telling the American scholar Richard Little Purdy a year later in conversation: 'One is not responsible at such a time. I never gave my consent, it never should have been done-it was contrary to Mr. Hardy's wish. ${ }^{28}$ On the one side, Florence was under pressure from two distinguished men who represented London and the 'nation's interests'; on the other, she would face in Dorchester a degree of suspicion and recrimination that would last for the remainder of her life.

On 18 January 1928, two days after the funeral, the humorous weekly Punch carried a brief composition by its Editor, Owen Seaman:

The Nation's Temple claims her noblest Dead,

So to its care his ashes we confide,

But where his heart would choose a lowlier bed

There lay it, in his own loved countryside. ${ }^{29}$

Seaman makes a neat play on the heart choosing where it would like to be laid, though in no respect criticising the absurdity of the division. Indeed, in a letter prompted by an appreciative message from Florence, Seaman explained that the ancient practice of a separate heart-burial was to be explained by the desire to preserve the heart from the flames. ${ }^{30}$

Recently I have come across two poems on the theme of that division, apparently submitted for publication in the latter half of January 1928 , though neither was accepted. One is by a poet celebrated then as now, Siegfried Sassoon, the other by one quite unknown to fame. What both poems share is a sense of indignation, even outrage, at what had happened to the man they knew. Sassoon had first visited Max Gate in November 1918, a meeting commemorated in some fine and lasting lines: 
He wore an air of never having heard

That there was much that needed putting right.

Hardy, the Wessex wizard, wasn't there.

On Hardy's death Sassoon composed a poem that was discovered only in 1975, among papers acquired by the Eton College Library. The poem was first printed in the Eton College Chronicle in 1980 and has been little noticed since. 'Catafalque' seems still to be in the drafting, but there is some biting force in the obviousness of the rhymes:

\section{CATAFALQUE}

Thomas Hardy is dead.

Panegyrics have been piled upon his head.

'The Last Great Victorian' -

Fleet Street re-echoed, unctuous and stentorian.

'In the Abbey let him rest'.

(His wishes were well known, but we know best).

This has been done

To the satisfaction of almost everyone.

'Thomas Hardy' meant

The antithesis of self-advertisement.

Now his renown is pooled.

Publishers are scrambling to be first in the field with books about him before the canonized combustion has cooled.

Thomas Hardy has died.

Upon his name the world has heaped its pride.

And those who love him

Stand silent with their genuine grief above him

Who stands no more upright

But has bequeathed them wisdom and compassionate sight. ${ }^{31}$

The last three couplets are clearly unfinished but the first five aspire to epigrammatic wit, while the sixth enforces in the voice the breathlessness it mocks. Sassoon's anger was widely shared, though seldom with such rhythmical craft; that anger, and any disapproval of how London and the Establishment had treated Hardy in death, was comprehensively kept out of the public eye by magazine editors.

The Wood Homer family of Puddletown had lived in Bardolf Manor since it was built in the 1890s, and before that in Athelhampton Hall. 
They were among the landed neighbours with whom in later life Hardy was on good terms. Christine Wood Homer (1883-1975), the daughter of Hardy's friends George and Elizabeth, was active in local history and archaeological circles, and the author in her old age of a pamphlet, Thomas Hardy and his two Wives (1964); her memories of Hardy reached back to the 1890s. In the Eton College Library is an unpublished poem in manuscript attributed to her: 'On Hearing that Thomas Hardy was to be buried at Westminster.' This poem seems to have been penned between the evening of Wednesday 11 January and the funeral on Monday the 16th. Which of these two versions, voiced in first or third-person (the third is given here), was sent to newspapers we do not know. It was never printed.

On Hearing that Thomas Hardy was to be buried at Westminster

Oh ye who knew how much he loved his land

How much he loved the spot where he was born

How oft he watched the twi'light turn to night

And saw the Darkness brighten to the morn

O'er that same Heath of which he wrote so oft

And where his truest dreams of life were born.

Oh do not take all that remains of him

To that dark Abbey-let his ashes lie

Beside the ones he ever loved so well

In the clean Earth beneath the country sky.

Fame is but passing show and vanity

Far more his love of Mother, sister, wife

Oh let him sleep his last Sleep near to them

Far from the seething roar of city life.

Westminster cannot hold the Soul of him

His shade, if it shall come to Earth again

Will not be there, but on that Egdon Heath

He ever loved in Sunshine or in rain. ${ }^{32}$

While this may not be a poem that deserves to be published in its own right, it has value as evidence of local and 'County' resentment at Hardy's ashes being laid to rest in the Abbey, and at the violation of the integrity of Hardy's corpse. Neither of these poems was published and it may be supposed that others of similar sentiments had been submitted, and were rejected.

Though the decision was taken by Cockerell and Barrie, both of whom returned to the wide world, it was Florence who had to live on at Max Gate with the sense that she had failed to honour her husband's wishes. 
Indeed, Cockerell did his very best to ensure that the public would think that the Abbey funeral was Florence's responsibility. On the evening of Friday 13 January, just as the heart was being surgically removed at Max Gate, this notice was placed by Cockerell in the Daily Mail:

Mrs. Hardy, after profound consideration, has accepted the Dean's offer. She felt that it was incumbent on her to do so in deference to the very strong body of opinion in favour of the honour which has been offered. She felt sure that although Mr. Hardy had expressed a wish to be buried in Stinsford Churchyard, near his home, the nation's desire in this matter must be obeyed. ${ }^{33}$

Hardy's Will had allowed for its own invalidation by the clause positing 'a separate paper', yet this statement concocted by Cockerell makes no mention of any such document. It might be taken to imply that there had been no separate paper, for Cockerell places the entire weight of his case on 'the nation's desire', and none at all on any desire expressed by Hardy, whether explicitly or implicitly. Forgoing any appeal to the writer's own wishes, Cockerell is constrained to advance an extraordinary claim: that the 'nation's desire' should outweigh Hardy's Will, and even that a 'very strong body of opinion' should outweigh the deceased's testament over the fate of his own body. It is not that the nation's wishes should be 'taken into account': no, they 'must be obeyed'. And who first articulated the nation's desire? Cockerell, with the help of Barrie, had pre-empted 'the nation's desire' even before Hardy had died. And who first proposed to the Dean of the Abbey that he should make an 'offer'? It was certainly not Florence. While the misrepresentation of Florence is blatant, we should also question the accuracy of Cockerell's representation of the Dean of Westminster, the Very Revd. William Foxley Norris. Is this how a Dean talks, or thinks? Cockerell seems to regard the Dean as not unlike a museum director, on the look-out for a prestigious acquisition: let's make an offer on those ashes, they ought to bring in the crowds. Whatever the Dean's thoughts or intentions, however, Cockerell was not mistaken in the consequences of that 'offer'-and the Abbey owes him much. ${ }^{34}$

As a means of creating shrines to attract pilgrims, the distribution of body-parts is a time-honoured practice, and one in which there should be no less of the saint's aura, or of the sacred, in a finger, a thighbone, a heart, or the body entire. Might a writer be fully present, as a saint is, in each of a number of locations where a part of the body solicits pilgrimage? In secular times, a life tends to have its places distributed: of birth, of education, of residence, of death, of burial. The devotion to Hardy sustains not only two burial sites but the Birthplace (at Higher Bockhampton) and Max Gate as properties regularly open to the public. 
There is no other major writer, in Britain at least, whose body has been, not by circumstance or accident (as with Shelley), but deliberately rent and distributed, and whose end cannot be told in terms of a single final resting-place. The occupants of other graves may be known to be incomplete but only of Hardy are we told both that his heart lies in Stinsford and that his ashes are in the Abbey. At the Abbey the stone reads 'Thomas Hardy O M 1840 1928' with no indication that anything less than the whole is present. ${ }^{35}$ Some visitors to Poets' Corner will assume Hardy to be resting there in his wholeness; visitors to Stinsford Churchyard are given a clue to an elsewhere in the wording 'Here lies the heart of Thomas Hardy', and beneath, the explanation: 'His ashes rest in Poets Corner Westminster Abbey.' Biographies of Hardy that attempt to narrate the events of Monday 16 January 1928 are obliged to switch back and forth between Florence and Kate in London with the ashes, and Henry with the heart in Stinsford. ${ }^{36}$ It is hard to make coherence of that day and its consequences; through all his life 'a time-torn man', Hardy has been severed into eternity. ${ }^{37}$

Millgate labours at some length to solve the serious problems posed by the 'apparent non-survival' of a separate paper, looking from every angle into the possibility that Hardy might have wanted to leave a loophole so that, should there be appropriate popular sentiment, he could be buried in Westminster Abbey. Yet one can study that will over decades and find no way out of perplexity. How could a lawyer commit such a fundamental mistake as to allow the possibility of a not-yet-existing piece of paper to supersede the very first paragraph of the will? A piece of paper yet to be addressed to the executors ought to be a codicil, and a codicil is by convention firmly attached to the will; it is both discursively dependent and physically proximate. The 'separate paper' in Hardy's Will is a phantom of a codicil.

On 17 October 1937 Florence Hardy died; she chose to be cremated, and thus to share the fate of her husband whose cremation had been a condition of burial in Poets' Corner. Yet Hardy's ashes in the Abbey will never mingle with hers in Stinsford Churchyard. Florence's ashes were placed in the tomb in which Emma's coffin was buried, with, at one end, Hardy's heart. Three in a grave: Hardy and Emma substantively there, though Thomas only partially so; Florence there in ashes with Thomas's heart, his ashes elsewhere. Though two pairs are interred in one tomb, neither pair can be thought united: these three, in one tomb, are from each other in death divided.

After all that Florence had endured in consequence of the words'according to consideration detailed in my directions to my Executors on a separate paper'-it is no surprise to find that the lawyer who drew up Florence's Will was not Hardy's lawyer. Nor is it with an unmixed sense of 
pride that the present writer records that the lawyer who drew up Hardy's Will was H. O. Lock, his grandfather.

\section{ABOUT THE AUTHOR}

Charles Lock, Professor of English Literature at the University of Copenhagen, was born and raised in Dorset. Educated at Oxford, where his doctoral thesis was on John Cowper Powys, he taught for some years at the University of Toronto. Author of Thomas Hardy: Criticism in Focus (1992) and numerous essays on Hardy's poetry, he is the Editor of the Powys Journal. Recent essays include 'A Quixotic Ramble along the Strand' (in StrandLines, 2019) and 'Derelictions of Contentment: on the locus amoenus in nineteenth-century landscape painting', in Mutating Idylls, ed. C. Meiner (Peter Lang, 2019). Among forthcoming articles is one on the editio princeps of the Codex argenteus, held in the Library of Uppsala University, and another on the city of Harbin understood within the geo-politics of north-east Asia, in Japan's Russia: Challenging the East-West Paradigm, ed. O. Solovieva (Cambria, 2020).E-mail: lock@ hum.ku.dk.

\section{WORKS CITED}

Bond, Jonathon. 'Pilgrimage to Lyonesse' [on papers acquired by Eton College Library in 1975], Eton College Chronicle, 1980.

Dancy, John. Walter Oakeshott: A Diversity of Gifts. Norwich: Michael Russell, 1995.

Egremont, Max. Siegfried Sassoon: A Biography. London: Picador, 2005.

Fincham, Tony. 'Chairman's Notes.' Thomas Hardy Society Journal 15:2 (Summer 2019) 5-7.

Ford, Mark. Thomas Hardy: Half a Londoner. Cambridge, MA: Harvard University Press, 2016.

Hardy, Kate. Diary (ms. unpublished). Dorset County Museum.

Hardy, Thomas. Life's Little Ironies. London: Osgood, McIlvaine, 1894.

Hardy, Thomas. Satires of Circumstance. London: Macmillan, 1914.

Hardy, Thomas. The Life and Work of Thomas Hardy, M. Millgate (ed.). London: Macmillan, 1984.

'History of Modern Cremation in History of Modern Cremation in Great Britain from 1874: The First Hundred Years Great Britain from 1874: The First Hundred Years (written in 1974 on the occasion of the Cremation Society's centenary)', The Cremation Society, https://www.cremation.org.uk/history-of-cremation-in-the-united-kingdom. Date accessed: 1 April 2020.

Millgate, Michael. Thomas Hardy: A Biography. Oxford: Oxford University Press, 1982.

Millgate, Michael. Testamentary Acts: Browning, Tennyson, James, Hardy. Oxford: Clarendon Press, 1992.

Millgate, Michael. (ed.). Letters of Emma and Florence Hardy. Oxford: Clarendon Press, 1996. Millgate, Michael. Thomas Hardy: A Biography Revisited. Oxford: Oxford University Press, 2004. Sassoon, Siegfried. 'Catafalque.' Eton College Chronicle 1980 (otherwise unpublished ms.). Eton College Library. 
Thomas Hardy's Will and Other Wills of His Family: Monographs on the Life, Times and Works of Thomas Hardy, no. 36. Guernsey C.I.: Toucan Press, 1967.

[Titterington, Nellie] Miss E.E.T. (Hardy's Parlour-Maid). The Domestic Life of Thomas Hardy (1921,1928). Beaminster: Toucan Press, 1963.

Wood Homer, Christine. 'On Hearing that Thomas Hardy was to be buried at Westminster' (ms. unpublished). Eton College Library.

Woolf, Virginia. The Diary of Virginia Woolf, Volume 3: 1925-30, Anne Olivier Bell (ed.). London: Hogarth Press, 1980.

\section{NOTES}

1 Ford, Mark. Thomas Hardy: Half a Londoner. Cambridge, MA: Harvard University Press, 2016 (1), alluding to 'Saul and Jonathan were lovely and pleasant in their lives, And in their death they were not divided' (2 Samuel 1:23). Among the best-known recensions of the phrase in English literature are as the last words of George Eliot's Mill on the Floss (1860), on the tomb holding Tom and Maggie Tulliver: "In their death they were not divided".' Note also the cruel end of Hardy's story, 'The History of the Hardcombs' (Life's Little Ironies, 1894): 'The two halves, intended by Nature to make the perfect whole, had failed in that result during their lives, though "in their death they were not divided".'

2 Hardy, Thomas. 'In Death Divided.' Satires of Circumstance. London: Macmillan, 1914 (35-36). Cited here are the last two of the poem's five stanzas.

3 The antithesis between the 'rustic' and the 'stately' is in the ms. between the Gothic and the classic, which may put the emphasis on a divergence of aesthetic attitudes rather than of social class. The significance of this emendation was noted early, by A.S. McDowell, Thomas Hardy: A Critical Study. London: Faber, 1931 (141-142).

4 Thomas Hardy's Will (1). On Hardy's determination that Emma should be buried in the plot already reserved for himself and his wife at Stinsford, see Millgate, Michael. Thomas Hardy: A Biography Revisited. Oxford: Oxford University Press, 2004 (446-447). Hardy also erected to Emma's memory a tablet in the church at St. Juliot, Cornwall (idem (451)); in the poem 'I Found Her Out There' Emma's shade is imaged as creeping underground 'Till it catch the sound/Of that western sea' (Hardy, Thomas, 1914 (102)).

5 Thomas Hardy's Will (6).

6 Cited in Dancy, John. Walter Oakeshott: a Diversity of Gifts. Norwich: Michael Russell, 1995 (25).

7 Millgate, Michael, 2004 (414, 475, 487, 539), and Millgate, Michael. Testamentary Acts: Browning, Tennyson, James, Hardy. Oxford: at the Clarendon Press, 1992 (140-141).

8 Millgate, Michael (ed.). Letters of Emma and Florence Hardy. Oxford: at the Clarendon Press, 1996 (261). This letter was sent on Sunday, followed by the urgent summons in a telegram on Monday morning.

9 Millgate, Michael. 1992 (141); see note 21 on p. 246: Cockerell's Diary for 12 January 1928 'refers to his conversation with Barrie at Max Gate on the 10th'.

10 Barrie arrived in Dorchester on Monday 9 January (Millgate, Michael, 2004 (530)), correcting the date of Tuesday 10 January given in Millgate, Michael. Thomas Hardy: A Biography. Oxford: Oxford University Press, 1982 (571); he left on Tuesday, after one night in a Dorchester hotel.

11 Millgate, Michael, 1992 (139-147), provides the most detailed account of the hours and days following Hardy's death; this is more attentive to legal and procedural aspects than the account in either Millgate, Michael, 1982 (570-578) or 2004 (532-540).

12 [Titterington, Nellie]. The Domestic Life of Thomas Hardy (1921-1928). Beaminster: Toucan Press, 1963 (16); Millgate, Michael, 2004 (532). According to a letter to his wife, 
of 12 January, Cockerell had, in the evening of 11 January, after Hardy's death, gone into Dorchester to send off other messages, before returning around $11 \mathrm{pm}$ to sleep again at Max Gate (Millgate, Michael, 1992 (141)).

13 Millgate, Michael, 1992 (140).

14 Diary of Kate Hardy (Dorset County Museum).

15 Millgate, Michael, 1992 (143). In a letter of 16 February 1928 to Hardy's publisher, Daniel Macmillan, Florence revealed a further grievance concerning 'my husband's "Instructions to my Executors" which are now filed in London, and which we are not allowed to have back' (Millgate, Michael (ed.), 1996 (269)). These 'Instructions' have never been found and are presumably to be identified with 'my directions to my Executors on a separate paper'. That Florence was 'not allowed' to have them back would help to account for the rapid deterioration in her relations with Cockerell; see Millgate, Michael, 1992 (160, 165-168).

16 In conversation with R. L. Purdy, Cockerell asserted that the heart-burial was Florence's idea; see Millgate, Michael, 1992 (247 note 41). This would be consistent with the notice published by Cockerell in the Daily Mail implying that the initiative for the Abbey funeral had come from Florence; Cockerell was keen to give the impression that he had all along been following her wishes and respecting her notions. Decades later, Cockerell attempted to justify his actions in a letter to the Times Literary Supplement, 22 January 1954; see Millgate, Michael, 1992 (143-144).

17 Idem (145-146). The proposal of a 'heart burial' may have found support in a lecture given to the Dorset Natural History and Archaeological Society at the Dorset County Museum, Dorchester, in the first half of December 1926 by the local antiquarian, G. Dru Drury, on 'Heart Burials and Some Purbeck Marble Heart-Shrines'. An offprint of this lecture (Dorchester, 1927) was found among the mail received at Max Gate shortly before Hardy's death; it had not been opened. See idem (145, 247, note 41).

18 Idem (146) records that Dr Mann took the biscuit-tin away and kept it at his home overnight; Nellie Titterington gives another version: 'After his death I attended his heartfuneral at Stinsford. Until the funeral Mrs. Hardy had kept Mr. Hardy's heart in my biscuit-tin.' ([Titterington, Nellie], 1963 (16)).

19 Ford, Mark, 2016 (facing 128) shows a rarely-printed photograph of the hearse leaving Max Gate on Saturday morning, 14 January, and proceeding, accompanied by mourners on foot, along the road to Dorchester, where the coffin would be placed on the train to Woking. Millgate, Michael, 2004 (535) supposes that the coffin was carried in the hearse all the way to Woking. (Hardy was cremated at Woking Crematorium, not at the quite separate, though nearby, Brookwood Crematorium.).

20 'History of Modern Cremation in History of Modern Cremation in Great Britain from 1874: The First Hundred Years Great Britain from 1874: The First Hundred Years (written in 1974 on the occasion of the Cremation Society's centenary),' https://www.cremation.org.uk/history-of-cremation-in-the-united-kingdom. Date accessed: 1 April 2020.

21 William Temple, Archbishop of Canterbury, had insisted that his body be cremated; his funeral in 1944 contributed to a considerable shift in the popular view of cremation, especially among churchgoers.

22 A third service, of commemoration, was held at the very same hour in Dorchester. Each service lasted for one hour. At 2 pm on Monday 16 January 1928, while one service was being held in London and another in Stinsford, the people of Dorchester gathered in St. Peter's (barely a mile across the meadows from Stinsford) to pay their respects to Hardy as a fellow-townsman; the Mayor decreed that all shops in Dorchester should be closed from 2 to 3 pm (see Millgate, Michael, 2004 (536)). It is worth noting that in the earliest years of broadcast media, sharing an experience from afar was still best achieved by participation in a parallel rite held simultaneously. Only later-with the 
most recent Coronation, or Churchill's funeral—would the televised representation of an event keep people at home, away from any simultaneous communal rite; later still, large screens would be used to encourage massed local gatherings in diverse locations, as for Princess Diana's funeral.

23 Diary of Kate Hardy, 13 January 1928.

24 The most concise and accurate account of the formal aspects of the two funerals is provided by Harold Child and is printed as Appendix 1 in Hardy, Thomas. The Life and Work of Thomas Hardy. M. Millgate (ed.). London: Macmillan, 1984 (485-486).

25 Woolf, Virginia. The Diary of Virginia Woolf, Volume 3: 1925-30. Anne Olivier Bell (ed.). London: Hogarth Press, 1980 (173-174). A similar point was made in a letter to T.E. Lawrence by Charlotte, wife of G. B. Shaw (Ford, Mark, 2016 (16)).

26 Diary of Kate Hardy, 16 January 1928.

27 Millgate, Michael, 2004 (535).

28 Millgate, Michael, 1992 (146).

29 Text printed in Millgate, Michael, 2004 (537).

30 Millgate, Michael (ed.), 1996 (266 note). This would account for the division of Shelley's corpse: his heart was 'rescued' by Trelawny from the pyre on the beach at Viareggio. Shelley's ashes were buried in the Protestant Cemetery at Rome, and decades later the heart (by then in ashes, or dust) was buried in St Peter's Church, Bournemouth.

31 Reproduced by permission of the Estate of Siegfried Sassoon (Barbara Levy Literary Agency) and of the Provost and Fellows of Eton College. This poem was first published in the Eton College Chronicle 1980 accompanying 'Pilgrimage to Lyonesse', Jonathon Bond's description of papers acquired by Eton College Library in 1975: a series of letters from Hardy to Sassoon, including the ms. of this unpublished poem. Partly quoted by Jeffrey Meyers in 'Thomas Hardy \& the Warriors', The New Criterion, 1 September 2002, the entire poem is published for only the second time on the present occasion. For assistance with the poems by Sassoon and by Christine Wood Homer, my thanks to Dr. Stephanie Coane, Curator of Modern Collections, College Library, Eton College, to Sally Jennings, Collections Administrator, Eton College Library, and to Michael Meredith, retired Librarian. 'Catafalque' has been little noted in Sassoon scholarship since 1980; Egremont, Max. Siegfried Sassoon: a Biography. London: Picador, 2005 (311) has described it, oddly, as 'a pompous elegy'. According to Egremont, 'Catafalque' was rejected by the Times, though the extant ms. at Eton seems to be a draft not ready for submission.

32 Published with the consent of the poet's nephew, Hugo Wood Homer of Bardolf Manor, Puddletown, Dorchester, and by permission of the Provost and Fellows of Eton College. Though no poet's name is given on the paper-a single leaf in manuscript, with one version on each side-her nephew confirms that this is Christine Wood Homer's hand.

33 Millgate, Michael, 1992 (145).

34 Space does not permit an account of the arguments, resolved within three days, over whether Hardy was a Christian or sufficiently 'churchy' to be given a funeral in the Abbey; see idem (141-143.) The 'offer' made by the Dean would follow a decision made by the Chapter based on two criteria for inclusion in Poets' Corner: literary merit and Christian faith. The burial there immediately previous to Hardy's was Tennyson's, in 1892; Hardy was present (Millgate, Michael, 2004 (305)). We can ask: of all those in Poets' Corner, which one exercises the strongest pull on visitors today?

35 The memorial tablet for Hardy in Poets' Corner became so worn-being set in the floor - that a replacement was called for and a new stone was laid at a ceremony held on 18 May 2019. The former stone was donated by the Abbey to the Thomas Hardy Society who intend to have it installed in Stinsford Church (Fincham, Tony, 'Chairman's Notes.' Thomas Hardy Society Journal 15:2 (Summer 2019) (6)); this will no doubt lead to further confusion, the sort likely to ensue when a label is preserved apart from what it labelled. 
36 The identity has recently been learnt of the stonemason who engraved the words on the stone at Stinsford (see Figure 1), and who placed the heart-casket therein: Leonard Hounsell (c.1891-c.1966). See the frustratingly vague account: http://www.hounsell. org.uk/hardy.html. Date accessed: 1 April 2020.

37 Though there are parallels, the cases of Shelley and Chopin are not comparable to Hardy's in that the removal of the heart was undertaken by friends or relatives, and Chopin's heart was buried in secret. Neither of these dividings had any official authorization, whereas the disposal of Hardy's remains was sanctioned by the Establishment: for one person, two funerals were conducted-according to the Rites and Ceremonies of the Church of England by Law established. 